\title{
Metabolizable energy values of diets supplemented with xylanase determined with laying hens
}

\author{
Karina Márcia Ribeiro de Souza ${ }^{1}$, Douglas Emygdio de Faria1', Vanessa de Souza Nakagi' \\ Ágatha Cristina de Pinho Carão ${ }^{1}$, Bruna Helena Carvalho Pacheco ${ }^{1}$, Renata Barbieri Trevisan ${ }^{1}$, \\ Gilson Alexandre Gomes ${ }^{2}$
}

\footnotetext{
${ }^{1}$ College of Animal Science and Food Engineering, USP, Pirassununga, SP.

${ }^{2} A B$ Vista Feed Ingredients.
}

\begin{abstract}
The objective of this study was to evaluate the effect of the supplementation of xylanase in diets with reduced energy level on the apparent metabolizable energy corrected for nitrogen, determined with laying hens at 14, 36, 60 and 80 weeks of age. Four digestibility trials were conducted, using 80 Hy-line W36 laying hens aged 14, 36, 60 and 80 weeks of age. Birds were distributed in a completely randomized design in $2 \times 2$ factorial arrangement (energy level $\times$ inclusion of xylanase), totaling four treatments with 10 replicates of two birds each. Treatments were: positive control (balanced diet for their age); positive control + xylanase; negative control (diet with reduction of $100 \mathrm{kcal} / \mathrm{kg}$ in the level of metabolizable energy); and negative control + xylanase. Xylanase, produced by microorganism Trichoderma reesei, was added to the diets at $100 \mathrm{~g} / \mathrm{t}$ $(16,000 \mathrm{BXU} / \mathrm{kg})$ for diets fed at 14 weeks and $75 \mathrm{~g} / \mathrm{t}$ for diets of 36,60 and 80 weeks $(12,000 \mathrm{BXU} / \mathrm{kg})$. The data obtained were subjected to analysis of variance at $5 \%$ probability. Supplementation of xylanase promoted higher values for AME (apparent metabolizable energy) and $\mathrm{AME}_{\mathrm{n}}$ (apparent metabolizable energy corrected for nitrogen) determined with 80-week-old laying hens, subjected to diet with energy level according to the nutritional requirements for their age. Supplementation of xylanase increases the matabolizability coefficient of the dietary crude protein and improves the nitrogen retention of laying hens at 14 weeks. In addition, xylanase associated with adequate levels of dietary energy promotes higher values for $\mathrm{AME}$ and $\mathrm{AME}_{\mathrm{n}}$ determined with laying hens at 80 weeks of age.
\end{abstract}

Key Words: corn, energy reduction, metabolizability coefficient, rearing

\section{Introduction}

It is known that, in laying hens, approximately $20 \%$ of energy is used for production; therefore, the decision of the amount to be provided is fundamental, since the bird will preferentially direct the energy for maintenance and decrease the production if the input is insufficient. A diet deficient in energy can cause a reduction in the growth of the bird, as well as decrease in the laying rate and weight loss (Leeson \& Summers, 1997).

Non-starch polysaccharides (NSP) stand out as one of the anti-nutritional factors. Corn, which is added to poultry feed as the main source of energy, contains only $1 \%$ of soluble NSP, especially arabinoxylans, compared with 24 , 45 and $46 \%$ for wheat, barley and rye, respectively (Choct, 2010). However, although maize is an easily-digested ingredient, there is evidence suggesting the presence of starch resistant to digestion, which may limit the value of corn energy and consequently of the dietary energy (Slominski, 2001).

Exogenous enzymes improve the nutritional value of corn and consequently of diets based on corn and soybean meal by several potential mechanisms (Cowieson, 2005). Among them, it is known that enzymes can hydrolyze polysaccharides that prevent the digestion of starch grains and protein, making these compounds available for digestion by the action of endogenous enzymes (Bedford, 1996).

Xylanase has been successfully used in the wheatbased diets, having a high content of arabinoxylans and reported success reducing the viscosity of the chyme and degradation of the cell wall. Moreover, it presents great tolerance to $\mathrm{pH}$, being effective in the range of 3.5 to 6.5 , so it can act from the beginning of digestion to the ileum (Costa et al., 2004).

In this context, although the presence of NSP in corn is not a major problem, the use of xylanase may be beneficial in diets based on corn and soybean meal for poultry, probably by improving the coefficients of nutrient digestibility, mediated by changes in the cell wall structure, once xylans and arabinoxylans undergoing hydrolisys, under the action of exogenous enzyme, can release encapsulated nutrients (Cowieson, 2005).

The objective of this study was to evaluate de effect of supplementation of xylanase in diets with reduced energy 
level on the apparent metabolizable energy and apparent metabolizable energy corrected for nitrogen, determined with laying hens at $14,36,60$ and 80 weeks of age.

\section{Material and Methods}

Four digestibility trials were conducted with 80 laying hens of the Hy-line strain variety W36 at the ages of 14, 36,60 and 80 weeks of age, housed in metabolism cages with dimensions $1.00 \times 0.50 \times 0.60 \mathrm{~m}$ arranged in battery, provided with front internal feeder, nipple drinking system and trays previously coated with plastic for the collection of excreta.

The trials were developed in two phases of rearing: growth (14 weeks) and laying (36, 60 and 80 weeks), and each trial consisted of five days of adaptation to diets and facilities and five days for collection of excreta. The birds were distributed in a completely randomized design in $2 \times 2$ factorial arrangement (energy level $\times$ inclusion of xylanase), totaling four treatments with 10 replicates of two birds each.

The treatments were: positive control (diet balanced according to age); positive control + xylanase; negative control (diet with reduction of $100 \mathrm{kcal} / \mathrm{kg}$ in metabolizable energy); and negative control + xylanase. The diets were based on corn and soybean meal and formulated to make up the requirements recommended by Rostagno et al. (2005), for periods of 13 to 17 weeks (Rearing II) and 33 to 80 weeks (Laying II), except for the energy level of the diets of negative control treatments (with or without inclusion of xylanase) (Tables 1 and 2). Water and feed were given ad libitum throughout the trial.

Xylanase (ECONASE XT25 ${ }^{\circledR}$ ), produced by the microorganism Trichoderma reesei, was added to the diets at $100 \mathrm{~g} / \mathrm{t}(16,000 \mathrm{BXU} / \mathrm{kg})$ for diets fed at 14 weeks and $75 \mathrm{~g} / \mathrm{t}$ for diets of 36,60 and 80 weeks $(12,000 \mathrm{BXU} / \mathrm{kg})$.

The method of total excreta collection was adopted, conducted in the four digestibility trials. The feed were weighed before and after collection periods for determining the feed intake, and marked with $1 \%$ ferric oxide to determine the beginning and end of the collections (Table 3 ).

During the collection period, the excreta were collected twice daily ( $8 \mathrm{~h} 00$ and $16 \mathrm{~h} 00$ ) to avoid loss of material, packed in plastic bags identified per experimental unit, and frozen for subsequent analysis.

At the end of the collection period, the excreta were joined per experimental unit, thawed, weighed and homogenized. From the homogeneous mass, a sample was collected and placed in a forced-ventilation oven, at a temperature of $55^{\circ} \mathrm{C}$ for 72 hours, in order to carry out the pre-drying. Subsequently, the pre-dried samples were exposed to air so that there was balance with the environment temperature and humidity. They were then weighed, ground and packed in plastic containers for laboratory analysis.

The contents of humidity, dry matter, nitrogen and ether extract of the excreta and feed were determined according to Silva \& Queiroz (2002), and gross energy by bomb calorimeter. From the results of laboratory analysis information of dry matter intake, metabolizability coefficients of dry matter, crude protein, ether extract, gross energy, value of apparent metabolizable energy and apparent metabolizable energy corrected for nitrogen retention of the feed and nitrogen retention per day were obtained. To calculate the apparent metabolizable energy and apparent metabolizable energy corrected for nitrogen retention and metabolizability coefficients, the formulas described by Matterson et al. (1965) apud Sakomura \& Rostagno (2007) were used.

Table 1 - Percentage and calculated composition of experimental diets for the trial of 14 weeks of age

\begin{tabular}{|c|c|c|c|c|}
\hline \multirow{2}{*}{ Ingredients } & \multicolumn{4}{|c|}{$\begin{array}{l}\text { Experimental diets }(\mathrm{g} / \mathrm{kg} \text { in natural } \\
\text { matter) }\end{array}$} \\
\hline & $\mathrm{PC}$ & $\begin{array}{c}\mathrm{PC}+ \\
\text { xylanase }\end{array}$ & $\mathrm{NC}$ & $\begin{array}{c}\mathrm{NC}+ \\
\text { xylanase }\end{array}$ \\
\hline Corn & 726.00 & 726.00 & 699.00 & 698.90 \\
\hline Soybean meal & 180.00 & 180.00 & 176.80 & 176.80 \\
\hline Wheat bran & 35.00 & 35.00 & 58.10 & 58.00 \\
\hline Soybean oil & 1.00 & 1.00 & 1.00 & 1.00 \\
\hline Econase XT 25 & - & 0.10 & - & 0.10 \\
\hline Dicalcium phosphate & 11.20 & 11.20 & 11.00 & 11.00 \\
\hline Limestone & 11.40 & 11.40 & 11.50 & 11.50 \\
\hline Salt & 1.90 & 1.90 & 1.90 & 1.90 \\
\hline Bicarbonate sodium & 1.50 & 1.50 & 1.50 & 1.50 \\
\hline Chlorine chloride & 0.30 & 0.30 & 0.30 & 0.30 \\
\hline Vitamin and mineral supplement & 4.00 & 4.00 & 4.00 & 4.00 \\
\hline Inert (kaolin) & 27.60 & 27.50 & 35.00 & 35.00 \\
\hline \multicolumn{5}{|l|}{ Calculated values } \\
\hline Metabolizable energy (kcal/kg) & 2.900 & 2.900 & 2.800 & 2.800 \\
\hline Crude protein $(\%)$ & 15.00 & 15.00 & 15.00 & 15.00 \\
\hline Linoleic acid (\%) & 1.62 & 1.62 & 1.60 & 1.60 \\
\hline Crude fiber $(\%)$ & 2.80 & 2.80 & 2.93 & 2.93 \\
\hline Calcium (\%) & 0.80 & 0.80 & 0.80 & 0.80 \\
\hline Available phosphorus (\%) & 0.31 & 0.31 & 0.31 & 0.31 \\
\hline Sodium (\%) & 0.15 & 0.15 & 0.15 & 0.15 \\
\hline Digestible methionine (\%) & 0.27 & 0.27 & 0.27 & 0.27 \\
\hline Digestible methionine+cystine $(\%)$ & 0.50 & 0.50 & 0.50 & 0.50 \\
\hline Digestible lysine (\%) & 0.62 & 0.62 & 0.62 & 0.62 \\
\hline
\end{tabular}

$\mathrm{PC}$ - positive control (diets with metabolizable energy requirement according to Rostagno et al (2005)); NC - negative control (reduction of $100 \mathrm{kcal} / \mathrm{kg}$ metabolizable energy in relation to positive control).

Levels $/ \mathrm{kg}$ of diet: vitamin A - 5,000 IU; vitamin D3 - 2,200 IU; vitamin E - $11.00 \mathrm{IU}$; vitamin K3 - $2.00 \mathrm{mg}$; vitamin B1 - $2.20 \mathrm{mg}$; vitamin B2 - $5.50 \mathrm{mg}$; vitamin B6 - $2.20 \mathrm{mg}$ vitamin B12 - $11.00 \mathrm{mcg}$; folic acid - $0.55 \mathrm{mg}$; biotin - $0.06 \mathrm{mg}$; pantothenic acid - $11.00 \mathrm{mg}$; niacin - $260.00 \mathrm{mg}$; coccidiostat - $0.13 \mathrm{~g}$; choline chloride - $0.50 \mathrm{~g}$; methionine $-0.45 \mathrm{~g}$; selenium (Se) - $0.20 \mathrm{mg}$; manganese (Mn) - $65.00 \mathrm{mg}$; copper $(\mathrm{Cu})-12.00 \mathrm{mg}$; zinc $(\mathrm{Zn})-50.00 \mathrm{mg}$; iron $(\mathrm{Fe})-50.00 \mathrm{mg}$; iodine (I) - $1.00 \mathrm{mg}$. 
The data were subjected to analysis of variance by the procedure PROC GLM of SAS (Statistical Analysis System, version 9.1), according to statistical model:

$$
\text { Yijk }=\mu+E i+Z j+(E x Z) i j+e i j k
$$

in which Yijk = observation of the characteristic in birds of the $\mathrm{k}$ experimental unit, of the energy level $\mathrm{i}$ and of the form of enzymatic supplementation $\mathrm{j} ; \mu=$ constant common to all experimental units; $\mathrm{Ei}=$ effect of the $\mathrm{i}$-th level of dietary energy $(i=1.2) ; \mathrm{Zj}=$ effect of the $\mathrm{j}$-th form of enzymatic supplementation $(\mathrm{j}=1.2) ; \mathrm{EZij}=$ effect

Table 2 - Percentage and calculated composition of experimental diets for the trials of 36,60 and 80 weeks of age

\begin{tabular}{|c|c|c|c|c|}
\hline \multirow{2}{*}{ Ingredients } & \multicolumn{4}{|c|}{$\begin{array}{c}\text { Experimental diets }{ }^{1}(\mathrm{~g} / \mathrm{kg} \text { in natural } \\
\text { matter })\end{array}$} \\
\hline & $\mathrm{PC}$ & $\begin{array}{c}\mathrm{PC}+ \\
\text { xylanase }\end{array}$ & $\mathrm{NC}$ & $\begin{array}{c}\mathrm{NC}+ \\
\text { xylanase }\end{array}$ \\
\hline Corn & 621.50 & 621.50 & 616.10 & 616.10 \\
\hline Soybean meal & 250.30 & 250.30 & 251.40 & 251.40 \\
\hline Soybean oil & 10.60 & 10.60 & 10.00 & 10.00 \\
\hline Econase XT 25 & - & 0.075 & - & 0.075 \\
\hline Dicalcium phosphate & 14.60 & 14.60 & 14.60 & 14.60 \\
\hline Fine limestone & 45.30 & 45.30 & 45.30 & 45.30 \\
\hline Granulated limestone & 45.30 & 45.30 & 45.30 & 45.30 \\
\hline Salt & 3.40 & 3.40 & 3.40 & 3.40 \\
\hline Bicarbonate sodium & 1.80 & 1.80 & 1.80 & 1.80 \\
\hline Chloride choline & 0.50 & 0.50 & 0.50 & 0.50 \\
\hline DL-metionine & 2.30 & 2.30 & 2.30 & 2.30 \\
\hline Lysine-HCl & 0.30 & 0.30 & 0.30 & 0.30 \\
\hline Vitamin and mineral supplement & 4.00 & 4.00 & 4.00 & 4.00 \\
\hline Inert (kaolin) & 0.15 & 0.075 & 14.00 & 13.90 \\
\hline \multicolumn{5}{|l|}{ Calculated values } \\
\hline Metabolizable energy (kcal/kg) & 2.800 & 2.800 & 2.700 & 2.700 \\
\hline Crude protein $(\%)$ & 16.89 & 16.89 & 16.89 & 16.89 \\
\hline Linoleic acid (\%) & 1.94 & 1.94 & 1.41 & 1.41 \\
\hline Crude fiber (\%) & 2.69 & 2.69 & 2.69 & 2.69 \\
\hline Calcium $(\%)$ & 3.94 & 3.94 & 3.94 & 3.94 \\
\hline Available phosphorus (\%) & 0.37 & 0.37 & 0.37 & 0.37 \\
\hline Sodium $(\%)$ & 0.22 & 0.22 & 0.22 & 0.22 \\
\hline Digestible methionine (\%) & 0.47 & 0.47 & 0.47 & 0.47 \\
\hline Digestible methionine+cystine (\%) & 0.71 & 0.71 & 0.71 & 0.71 \\
\hline Digestible lysine (\%) & 0.78 & 0.78 & 0.78 & 0.78 \\
\hline
\end{tabular}

PC - positive control (diets with metabolizable energy requirement according to Rostagno et al (2005)); NC - negative control (reduction of $100 \mathrm{kcal} / \mathrm{kg}$ metabolizable energy in relation to positive control).

Levels/kg of diet: vitamin A - 7,000 IU; vitamin D3 - 2,000 IU; vitamin E - $5.00 \mathrm{IU}$; vitamin K3 - $1.00 \mathrm{mg}$; vitamin B1 - $1.44 \mathrm{mg}$; vitamin B2 - $3.57 \mathrm{mg}$; vitamin B6 - $0.50 \mathrm{mg}$; vitamin B12 - $10.00 \mathrm{mcg}$; folic acid - $0.50 \mathrm{mg}$; pantothenic acid $-8.00 \mathrm{mg}$; niacin - $17.68 \mathrm{mg}$; methionine - $0.35 \mathrm{~g}$; selenium (Se) - $0.30 \mathrm{mg}$; manganese $(\mathrm{Mn})$ $68.80 \mathrm{mg}$; copper $(\mathrm{Cu})-12.00 \mathrm{mg}$; zinc $(\mathrm{Zn})-50.00 \mathrm{mg}$; iron $(\mathrm{Fe})-46.00 \mathrm{mg}$; iodine (I) $-1.00 \mathrm{mg}$.

Table 3 - Body weight at the beginning of the period of collection of excreta from laying hens fed diets containing xylanase

\begin{tabular}{lccccc}
\hline \multirow{2}{*}{ Energy } & \multirow{2}{*}{ Xylanase } & \multicolumn{4}{c}{ Initial body weight $^{1}(\mathrm{~g})$} \\
\cline { 3 - 6 } & & 14 weeks & 36 weeks & 60 weeks & 80 weeks \\
\hline Required & No & 1,040 & 1,524 & 1,556 & 1,550 \\
& Yes & 996 & 1,549 & 1,548 & 1,590 \\
\multirow{2}{*}{ Reduced } & No & 1,038 & 1,538 & 1,538 & 1,562 \\
& Yes & 1,019 & 1,521 & 1,544 & 1,571 \\
\hline
\end{tabular}

${ }^{1} \mathrm{P}>0.05$ of the interaction of the i-th energy level and $\mathrm{j}$-th form of enzymatic supplementation; eijk = error associated with the observation Yijk; eijk $\sim \mathrm{N}\left(0, \sigma^{2}\right)$.

\section{Results and Discussion}

There was interaction $(\mathrm{P}<0.05)$ between the factors for apparent metabolizable energy and apparent metabolizable energy corrected for nitrogen retention determined at 14 weeks of age (Table 4). The supplementation with the enzyme xylanase showed higher $(\mathrm{P}<0.05)$ percentage of metabolizability coefficient of the dietary crude protein; likewise, there was greater nitrogen retention per day.

It can be inferred that the xylanase supplementation was effective in reducing the viscosity of the digesta, improving the digestibility and protein adsorption, and probably lowering the amount of available substrate for bacterial fermentation in the growth stage of the poultry. Starch and protein in the diet that were not used by the animal can favor the migration of microorganisms, which would typically be found in large quantities in the poultry caecum, to the small intestine, which is the place of greatest absorption of nutrients (Campbell \& Bedford, 1992).

Although not observed in this study, the high bacterial load would possibly irritate the intestinal epithelium, promoting a thickened mucosa, damaged microvilli and reduction in nutrient absorption. This could have implications for the economy of poultry protein, in other words, the synthesis of more protein given the growth of organs, enzyme secretion and repair of intestinal mucosa could promote a reduction in the availability of protein for tissue growth or egg production in chickens (Jaroni et al., 1999).

The highest values $(\mathrm{P}<0.05)$ of apparent metabolizable energy and apparent metabolizable energy corrected for nitrogen retention were obtained for diets balanced according to nutritional recommendation for their age without enzyme supplementation determined with laying hens at 14 weeks (Table 5).

Probably, the values of apparent metabolizable energy and apparent metabolizable energy corrected for nitrogen retention, determined with laying hens at 14 weeks of age, were results of availability in the diet with 100 more kcal of $\mathrm{ME} / \mathrm{kg}$ ( $\mathrm{ME}=$ metabolizable energy) than in the diets formulated with the recommended energy level. However, it was expected that xylanase supplementation, in diets with reduced energy level, could promote similar or greater effects than those found in diets without supplementation and with the recommended energy level. 
Table 4 - Metabolizability coefficients, metabolizable energy and nitrogen retention of 14-week-old laying hens fed diets containing xylanase ${ }^{1}$

\begin{tabular}{|c|c|c|c|c|c|c|c|c|c|}
\hline \multirow[b]{2}{*}{ Energy } & \multirow[b]{2}{*}{ Xylanase } & \multicolumn{8}{|c|}{ Variables $^{2}$} \\
\hline & & $\begin{array}{l}\text { DMI } \\
(\mathrm{g})\end{array}$ & $\begin{array}{c}\text { MCDM } \\
(\mathrm{g} / \mathrm{g})\end{array}$ & $\begin{array}{c}\text { MCCP } \\
(\mathrm{g} / \mathrm{g})\end{array}$ & $\begin{array}{c}\text { MCEE } \\
(\mathrm{g} / \mathrm{g})\end{array}$ & $\begin{array}{c}\text { MCCE } \\
(\mathrm{g} / \mathrm{g})\end{array}$ & $\begin{array}{c}\mathrm{AME} \\
(\mathrm{kcal} / \mathrm{kg})\end{array}$ & $\begin{array}{c}\text { AMEn } \\
(\mathrm{kcal} / \mathrm{kg})\end{array}$ & $\begin{array}{c}\mathrm{NR} \\
(\mathrm{g} \mathrm{N} / \mathrm{d})\end{array}$ \\
\hline REQ & No & 394 & 0.739 & 0.460 & 0.946 & 0.813 & 3,703 & 3,590 & 1.10 \\
\hline \multirow[t]{2}{*}{ RED } & No & 428 & 0.733 & 0.499 & 0.945 & 0.795 & 3,389 & 3,263 & 1.29 \\
\hline & Yes & 423 & 0.738 & 0.532 & 0.944 & 0.794 & 3,282 & 3,140 & 1.46 \\
\hline \multicolumn{10}{|l|}{$\mathrm{XL}$} \\
\hline No & & 411 & 0.736 & $0.480 \mathrm{~b}$ & 0.946 & 0.804 & 3,554 & 3,435 & $1.19 \mathrm{~b}$ \\
\hline Yes & & 414 & 0.739 & $0.536 \mathrm{a}$ & 0.939 & 0.798 & 3,413 & 3,270 & $1.44 \mathrm{a}$ \\
\hline CV (\%) & & 9.54 & 1.00 & 7.72 & 1.93 & 1.13 & 1.12 & 1.02 & 14.56 \\
\hline \multicolumn{10}{|l|}{$P_{\text {value }}^{3}$} \\
\hline
\end{tabular}

Means followed by different letters in the column are significantly different by the $\mathrm{F}$ test.

${ }^{1} \mathrm{EN}$ - energy; XL - xylanase; REQ - diet formulated as recommended by Rostagno et al. (2005) for their age; RED - diet with reduction of $100 \mathrm{kcal} / \mathrm{kg}$ metabolizable energy in relation to REQ; DMI - dry matter intake; MCDM - metabolizability coefficient of dry matter; MCCP - metabolizability coefficient of crude protein; MCEE - metabolizability coefficient of ether extract; MCCE - metabolizability coefficient of crude energy; AME - apparent metabolizable energy; AMEn - apparent metabolizable energy corrected for nitrogen; NR - nitrogen retention; $\mathrm{CV}$ - coefficient of variation.

${ }^{2}$ Data expressed on a dry matter basis.

${ }^{3} \mathrm{EN}, \mathrm{XL}, \mathrm{EN} \times \mathrm{XL}=$ effect of the energy level of diet, supplementation of xylanase and their interaction, respectively.

Table 5 - Deployment of metabolizable energy determined with laying hens fed diets containing xylanase at 14 weeks of age

\begin{tabular}{lccc}
\hline \multirow{2}{*}{ Energy $^{1}$} & \multicolumn{2}{c}{ Xylanase } & Mean \\
\cline { 2 - 3 } & \multicolumn{2}{c}{ No } & YME $(\mathrm{kcal} / \mathrm{kg})$ \\
Required & $3,703 \mathrm{Aa}$ & $3,518 \mathrm{Ab}$ & 3,611 \\
Reduced & $3,389 \mathrm{Ba}$ & $3,282 \mathrm{Bb}$ & 3,338 \\
Mean & 3,554 & 3,413 & \\
CV (\%) & \multicolumn{3}{c}{1.12} \\
\multicolumn{2}{c}{ AMEn $(\mathrm{kcal} / \mathrm{kg})$} \\
Required & $3,590 \mathrm{Aa}$ & $3,375 \mathrm{Ab}$ \\
Reduced & $3,263 \mathrm{Ba}$ & $3,140 \mathrm{Bb}$ \\
Mean & 3,435 & 3,270 \\
CV (\%) & \multicolumn{3}{c}{1.02} \\
\hline
\end{tabular}

Means followed by different uppercase letters in the same column and different lowercase letters in the same row differ significantly by the $\mathrm{F}$ test $(\mathrm{P}<0.05)$.

AME - apparent metabolizable energy; AMEn - apparent metabolizable energy corrected for nitrogen; CV - coefficient of variation.

${ }^{1}$ Energy required under Rostagno et al. (2005); reduced in $100 \mathrm{kcal} / \mathrm{kg}$ compared to required energy.

Novak et al. (2007) observed greater energy retention (kcal/bird/day) for birds subjected to diets with reduction in the energy level and supplementation of enzyme complex (amylase + protease + xylanase) during the growth period (10 to 15 weeks).

Interaction $(\mathrm{P}<0.05)$ was observed between the factors for metabolizability coefficient of dry matter, crude protein, metabolizable energy corrected for nitrogen retention and nitrogen retention (Table 6).
The values of dry matter intake and metabolizability coefficient of ether extract at 36 weeks were higher $(\mathrm{P}<0.05)$ for the birds subjected to diets with reduction in the energy level at $100 \mathrm{kcal} / \mathrm{kg}$. Likewise, the factor energy influenced the metabolizability coefficient of the gross energy and apparent metabolizable energy; however, the highest values were obtained for diets with adequate energy level for their age. The increase in dry matter intake observed was expected, since poultry increase the feed intake in an attempt to supplement their demand for energy.

Xylanase, associated with the reduction of dietary energy, reduced the metabolizability coefficient of dry matter at 36 weeks of age, but promoted better results $(\mathrm{P}<0.05)$ for metabolizability coefficient of crude protein and nitrogen retention and less apparent metabolizable energy corrected for nitrogen retention when the enzyme was added to the diet with recommended energy level for the age of laying hens (Table 7).

The highest values for metabolizability coefficient of crude protein and nitrogen retention indicated that xylanase supplementation could improve the digestibility of nutrients such as protein and amino acids by reduction of intestinal viscosity. Choct et al. (1996) report that the digestibility of starch, protein and lipid can be significantly improved by enzyme supplementation in diets containing NSP.

Novak et al. (2008) found that the interaction between enzyme supplementation and level of dietary energy 
Table 6 - Metabolizability coefficients, metabolizable energy and nitrogen retention of 36-week-old laying hens fed diets containing xylanase

\begin{tabular}{|c|c|c|c|c|c|c|c|c|c|}
\hline \multirow[b]{2}{*}{ Energy } & \multirow[b]{2}{*}{ Xylanase } & \multicolumn{8}{|c|}{ Variables $^{1}$} \\
\hline & & $\begin{array}{c}\text { DMI } \\
(\mathrm{g})\end{array}$ & $\begin{array}{c}\text { MCDM } \\
(\mathrm{g} / \mathrm{g})\end{array}$ & $\begin{array}{c}\mathrm{MCCP} \\
(\mathrm{g} / \mathrm{g})\end{array}$ & $\begin{array}{c}\mathrm{MCEE} \\
(\mathrm{g} / \mathrm{g})\end{array}$ & $\begin{array}{c}\mathrm{MCCE} \\
(\mathrm{g} / \mathrm{g})\end{array}$ & $\begin{array}{c}\text { AME } \\
(\mathrm{kcal} / \mathrm{kg})\end{array}$ & $\begin{array}{c}\text { AMEn } \\
(\mathrm{kcal} / \mathrm{kg})\end{array}$ & $\begin{array}{c}\mathrm{NR} \\
(\mathrm{g} \mathrm{N} / \mathrm{d}) \\
\end{array}$ \\
\hline REQ & Yes & 641 & 0.765 & 0.560 & 0.938 & 0.823 & 3,299 & 3,163 & 2.09 \\
\hline \multirow[t]{2}{*}{ RED } & No & 667 & 0.759 & 0.531 & 0.952 & 0.809 & 3,108 & 2,981 & 2.05 \\
\hline & Yes & 687 & 0.740 & 0.420 & 0.949 & 0.807 & 3,112 & 3,001 & 1.86 \\
\hline \multicolumn{10}{|c|}{ EN } \\
\hline \multicolumn{10}{|l|}{ XL } \\
\hline No & & 651 & 0.757 & 0.509 & 0.946 & 0.814 & 3,222 & 3,108 & 1.95 \\
\hline Yes & & 665 & 0.752 & 0.516 & 0.944 & 0.815 & 3,205 & 3,082 & 1.97 \\
\hline CV (\%) & & 8.54 & 1.85 & 7.68 & 1.51 & 1.83 & 1.85 & 1.75 & 12.17 \\
\hline \multicolumn{10}{|l|}{$\mathrm{P}_{\text {value }}{ }^{2}$} \\
\hline
\end{tabular}

Means followed by different letters in the same column differ significantly by the $\mathrm{F}$ test.

EN - energy; XL - xylanase; REQ - diet formulated as recommended by Rostagno et al. (2005) for their age; RED - diet with reduction of $100 \mathrm{kcal} / \mathrm{kg}$ metabolizable energy in relation to REQ; DMI - dry matter intake; MCDM - metabolizability coefficient of dry matter; MCCP - metabolizability coefficient of crude protein; MCEE - metabolizability coefficient of ether extract; MCCE - metabolizability coefficient of crude energy; AME - apparent metabolizable energy; AMEn - apparent metabolizable energy corrected for nitrogen; NR - nitrogen retention; CV - coefficient of variation.

${ }^{1}$ Data expressed on a dry matter basis.

${ }^{2} \mathrm{EN}, \mathrm{XL}, \mathrm{EN} \times \mathrm{XL}$ - effect of the energy level of diet, supplementation of xylanase and their interaction, respectively.

Table 7 - Deployment for metabolizability of dry matter, crude protein, metabolizable energy and nitrogen retention determined with laying hens fed diets containing xylanase at 36 weeks of age ${ }^{1}$

\begin{tabular}{|c|c|c|c|}
\hline \multirow{2}{*}{ Energy 1} & \multicolumn{2}{|c|}{ Xylanase } & \multirow{2}{*}{ Mean } \\
\hline & No & Yes & \\
\hline \multicolumn{4}{|c|}{$\operatorname{MCDM}(\mathrm{g} / \mathrm{g})$} \\
\hline Required & $0.755 \mathrm{Aa}$ & $0.765 \mathrm{Aa}$ & 0.760 \\
\hline Reduced & $0.759 \mathrm{Aa}$ & $0.740 \mathrm{Bb}$ & 0.749 \\
\hline Mean & 0.757 & 0.752 & \\
\hline CV (\%) & & & \\
\hline \multicolumn{4}{|c|}{$\operatorname{MCCP~}(\mathrm{g} / \mathrm{g})$} \\
\hline Required & $0.481 \mathrm{Bb}$ & $0.560 \mathrm{Aa}$ & 0.525 \\
\hline Reduced & $0.531 \mathrm{Aa}$ & $0.472 \mathrm{Bb}$ & 0.501 \\
\hline Mean & 0.509 & 0.52 & \\
\hline CV (\%) & & & \\
\hline \multicolumn{4}{|c|}{ AMEn $(\mathrm{kcal} / \mathrm{kg})$} \\
\hline Required & $3,248 \mathrm{Aa}$ & $3,163 \mathrm{Ab}$ & 3,203 \\
\hline Reduced & $2,981 \mathrm{Ba}$ & $3,001 \mathrm{Ba}$ & 2,991 \\
\hline Mean & 3,108 & 3,082 & \\
\hline CV (\%) & & & \\
\hline \multicolumn{4}{|c|}{ NR (g N/d) } \\
\hline Required & $1.84 \mathrm{Ab}$ & 2.09Aa & 1.97 \\
\hline Reduced & $2.05 \mathrm{Aa}$ & $1.86 \mathrm{Ba}$ & 1.95 \\
\hline Mean & 1.95 & 1.97 & \\
\hline CV (\%) & \multicolumn{2}{|c|}{12.17} & \\
\hline
\end{tabular}

Means followed by different uppercase letters in the same column and different lowercase letters in the same row differ significantly by the $\mathrm{F}$ test $(\mathrm{P}<0.05)$.

MCDM - metabolizability coefficient of dry matter; MCCP - metabolizability coefficient of crude protein; AMEn - apparent metabolizable energy corrected for nitrogen; NR - nitrogen retention; CV - coefficient of variation.

${ }^{1}$ Energy requirement according to Rostagno et al. (2005); Reduced in $100 \mathrm{kcal} / \mathrm{kg}$ in relation to the energy requirement. resulted in differences in the percentage of energy retention at 38 weeks of age. The same authors reported that the absence of enzyme supplementation (amylase + protease + xylanase) promoted greater percentage of energy retention in laying hens fed diets formulated with recommended energy level for their age compared with those with a $3 \%$ reduction in the energy level; however, associated with enzymatic supplementation, the level of dietary energy did not influence the percentage of retained energy.

Furthermore, laying hens fed diets with recommended energy level for their age and supplementation of enzymatic complex (amylase + protease + xylanase) showed reduction in the percentage of protein retention at the age of 38 weeks (Novak et al., 2008).

It was found that only apparent metabolizable energy and apparent metabolizable energy corrected for nitrogen retention, determined at 60 weeks of age, were affected by treatments, with interaction $(\mathrm{P}<0.05)$ observed between the factors level of dietary energy and xylanase supplementation (Table 8).

It was found that diets formulated to meet the energy requirement and without xylanase presented apparent metabolizable energy and apparent metabolizable energy corrected for nitrogen retention superior $(\mathrm{P}<0.05)$ to those formulated with reduced energetic level (Table 9). It was observed that the xylanase supplementation to the diet with reduced energetic level resulted in apparent metabolizable energy and apparent metabolizable energy corrected for 
Table 8 - Metabolizability coefficients, metabolizable energy and nitrogen retention of laying hens at 60 weeks of age fed diets containing xylanase ${ }^{1}$

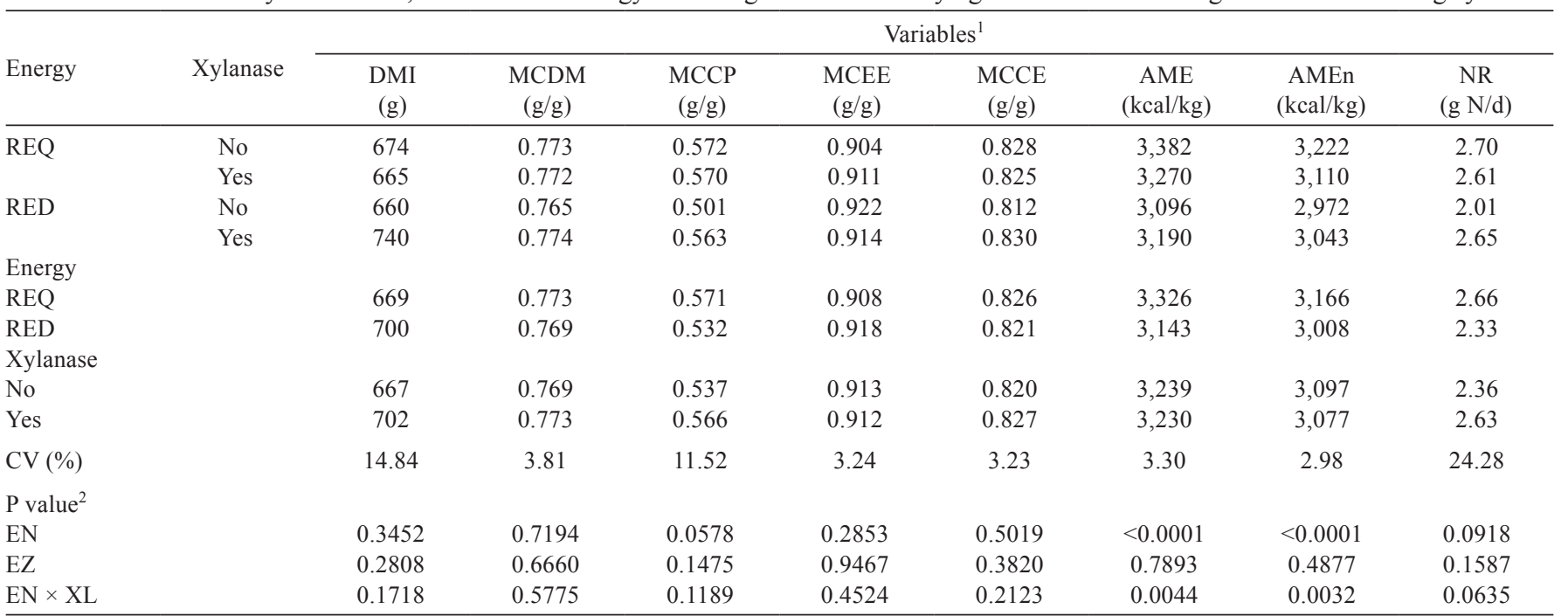

EN - energy; XL - xylanase; REQ - diet formulated as recommended by Rostagno et al. (2005) for their age; RED - diet with reduction of $100 \mathrm{kcal} / \mathrm{kg}$ metabolizable energy in relation to REQ; DMI - dry matter intake; MCDM - metabolizability coefficient of dry matter; MCCP - metabolizability coefficient of crude protein; MCEE - metabolizability coefficient of ether extract; MCCE - metabolizability coefficient of crude energy; AME - apparent metabolizable energy; AMEn - apparent metabolizable energy corrected for nitrogen; NR - nitrogen retention; CV - coefficient of variation.

${ }^{1}$ Data expressed on a dry matter basis.

${ }^{2} \mathrm{EN}, \mathrm{XL}, \mathrm{EN} \times \mathrm{XL}-$ effect of the energy level of diet, supplementation of xylanase and their interaction, respectively.

Table 9 - Deployment for metabolizable energy determined with laying hens fed diets containing xylanase at 60 weeks of age

\begin{tabular}{lccc}
\hline \multirow{2}{*}{ Energy $^{1}$} & \multicolumn{2}{c}{ Xylanase } & Mean \\
\cline { 2 - 3 } & \multicolumn{2}{c}{ No } & YME $(\mathrm{kcal} / \mathrm{kg})$ \\
Required & $3,382 \mathrm{Aa}$ & $3,270 \mathrm{Ab}$ & 3.326 \\
Reduced & $3,096 \mathrm{Ba}$ & $3,190 \mathrm{Aa}$ & 3.143 \\
Mean & 3,239 & 3,230 \\
CV (\%) & \multicolumn{3}{c}{3.30} \\
\multicolumn{4}{c}{ AMEn $(\mathrm{kcal} / \mathrm{kg})$} \\
Required & $3,222 \mathrm{Aa}$ & $3,110 \mathrm{Ab}$ & 3.166 \\
Reduced & $2,972 \mathrm{Ba}$ & $3,043 \mathrm{Aa}$ & 3.008 \\
Mean & 3,097 & 3,077 \\
CV (\%) & \multicolumn{3}{c}{2.98} \\
\hline
\end{tabular}

Means followed by different uppercase letters in the same column and lowercase letters in the same row differ significantly by the $\mathrm{F}$ test.

AME - apparent metabolizable energy; AMEn - apparent metabolizable energy corrected for nitrogen; CV - coefficient of variation.

${ }^{1}$ Energy requirement according to Rostagno et al. (2005); Reduced in $100 \mathrm{kcal} / \mathrm{kg}$ in relation to the energy requirement.

nitrogen similar $(\mathrm{P}<0.05)$ to those of the diet formulated according to nutritional requirement.

Interaction $(\mathrm{P}<0.05)$ was observed between the factors energy and xylanase for metabolizability coefficient of crude protein, apparent metabolizable energy and apparent metabolizable energy corrected for nitrogen retention determined with 80-week-old laying hens (Table 10). The energy factor influenced $(\mathrm{P}<0.05)$ dry matter intake, metabolizability coefficient of dry matter and of crude protein, and the diets formulated according to the recommendations of Rostagno et al. (2005) promoted lower $(\mathrm{P}<0.05)$ intake of crude protein and higher $(\mathrm{P}<0.05)$ percentage for metabolizability coefficient of dry matter and crude protein.

It was also found that xylanase supplementation reduced $(\mathrm{P}<0.05)$ the nitrogen retention. However, the xylanase supplementation promoted higher values $(\mathrm{P}<0.05)$ for metabolizability coefficient of gross energy, apparent metabolizable energy and apparent metabolizable energy corrected for nitrogen retention determined with 80 -weekold laying hens, subjected to diet with energy level according to the nutritional requirement for their age (Table 11).

In an experiment with broilers, Mathlouthi et al. (2003) observed better digestibility of nutrients and of apparent metabolizable energy in diets composed of corn, rice meal and barley, supplemented with xylanase $+\beta$-glucanase. Cowieson et al. (2006), working with reduction in the level of dietary energy and addition of enzymatic complex (xylanase + protease + amylase + phytase $)$ in diets for broilers observed intake values of digestible fractions (dry matter, nitrogen, energy) greater than or similar to those resulting from supply of diets formulated with adequate nutritional levels without inclusion of enzyme.

On the other hand, Viana (2009), studying the comparison of productive parameters from the supply of diets based on corn and soybean meal, with adequate nutritional levels or reduction in the percentage of the apparent metabolizable energy and xylanase supplementation, reported that the mean value of apparent 
Table 10 - Metabolizability coefficients, metabolizable energy and nitrogen retention of laying hens at 80 weeks of age fed diets containing xylanase

\begin{tabular}{|c|c|c|c|c|c|c|c|c|c|}
\hline \multirow[b]{2}{*}{ Energy } & \multirow[b]{2}{*}{ Xylanase } & \multicolumn{8}{|c|}{ Variables $^{1}$} \\
\hline & & $\begin{array}{l}\text { DMI } \\
(\mathrm{g})\end{array}$ & $\begin{array}{c}\mathrm{MCDM} \\
(\mathrm{g} / \mathrm{g})\end{array}$ & $\begin{array}{c}\mathrm{MCCP} \\
(\mathrm{g} / \mathrm{g})\end{array}$ & $\begin{array}{c}\text { MCEE } \\
(\mathrm{g} / \mathrm{g})\end{array}$ & $\begin{array}{c}\text { MCCE } \\
(\mathrm{g} / \mathrm{g})\end{array}$ & $\begin{array}{c}\mathrm{AME} \\
(\mathrm{kcal} / \mathrm{kg})\end{array}$ & $\begin{array}{c}\text { AMEn } \\
(\mathrm{kcal} / \mathrm{kg})\end{array}$ & $\begin{array}{c}\mathrm{NR} \\
(\mathrm{g} \mathrm{N} / \mathrm{d})\end{array}$ \\
\hline & Yes & 636 & 0.765 & 0.567 & 0.882 & 0.830 & 3,376 & 3,233 & 2.22 \\
\hline \multirow[t]{2}{*}{ RED } & No & 693 & 0.738 & 0.524 & 0.817 & 0.817 & 3,246 & 3,111 & 2.28 \\
\hline & Yes & 718 & 0.736 & 0.488 & 0.880 & 0.816 & 3,240 & 3,125 & 2.03 \\
\hline \multicolumn{10}{|l|}{ XL } \\
\hline No & & 682 & 0.743 & 0.544 & 0.837 & 0.812 & 3,242 & 3,100 & $2.35 \mathrm{a}$ \\
\hline Yes & & 677 & 0.740 & 0.527 & 0.851 & 0.823 & 3,308 & 3,179 & $2.12 \mathrm{~b}$ \\
\hline CV (\%) & & 9.83 & 2.89 & 9.34 & 9.47 & 1.92 & 1.93 & 1.84 & 14.58 \\
\hline \multicolumn{10}{|l|}{$P_{\text {value }}^{2}$} \\
\hline
\end{tabular}

Means followed by different letters in the same column differ significantly by the $\mathrm{F}$ test.

EN - energy; XL - xylanase; REQ - diet formulated as recommended by Rostagno et al. (2005) for their age; RED - diet with reduction of $100 \mathrm{kcal} / \mathrm{kg}$ metabolizable energy in relation to REQ; DMI - dry matter intake; MCDM - metabolizability coefficient of dry matter; MCCP - metabolizability coefficient of crude protein; MCEE - metabolizability coefficient of ether extract; MCCE - metabolizability coefficient of crude energy; AME - apparent metabolizable energy; AMEn - apparent metabolizable energy corrected for nitrogen; NR - nitrogen retention; CV - coefficient of variation.

${ }^{1}$ Data expressed on a dry matter basis.

${ }^{2} \mathrm{EN}, \mathrm{XL}, \mathrm{EN} \times \mathrm{XL}-$ effect of the energy level of diet, supplementation of xylanase and their interaction, respectively.

metabolizable energy corrected for nitrogen retention, determined with laying hens between 24 and 48 weeks of age, was greater for the diet with adequate level of apparent metabolizable energy, but found no significant difference

Table 11 - Deployment for metabolizability coefficients of gross energy and apparent metabolizable energy determined with laying hens fed diets containing xylanase at 80 weeks of age

\begin{tabular}{|c|c|c|c|}
\hline \multirow{2}{*}{ Energy $^{1}$} & \multicolumn{2}{|c|}{ Xylanase } & \multirow{2}{*}{ Mean } \\
\hline & No & Yes & \\
\hline \multicolumn{4}{|c|}{$\operatorname{MCCE}(\mathrm{g} / \mathrm{g})$} \\
\hline Required & $0.807 \mathrm{Ab}$ & $0.830 \mathrm{Aa}$ & 0.819 \\
\hline Reduced & $0.817 \mathrm{Aa}$ & $0.816 \mathrm{Ba}$ & 0.816 \\
\hline Mean & 0.812 & 0.823 & \\
\hline CV (\%) & & $\cos (\%)$ & \\
\hline \multicolumn{4}{|c|}{ AME (kcal/kg) } \\
\hline Required & $3,238 \mathrm{Ab}$ & $3,376 \mathrm{Aa}$ & 3,307 \\
\hline Reduced & $3,246 \mathrm{Aa}$ & $3,240 \mathrm{Ba}$ & 3,243 \\
\hline Mean & 3,242 & 3,308 & \\
\hline CV (\%) & & & \\
\hline \multicolumn{4}{|c|}{ AMEn (kcal/kg) } \\
\hline Required & $3,088 \mathrm{Ab}$ & $3,233 \mathrm{Aa}$ & 3,161 \\
\hline Reduced & $3,111 \mathrm{Aa}$ & $3,125 \mathrm{Ba}$ & 3,118 \\
\hline Mean & 3,100 & 3,179 & \\
\hline CV (\%) & \multicolumn{2}{|c|}{1.84} & \\
\hline
\end{tabular}

Means followed by different uppercase letters in the same column and different lowercase letters in the same row differ significantly by the $\mathrm{F}$ test $(\mathrm{P}<0.05)$.

MCCE - metabolizability coefficient of crude energy; AME - apparent metabolizable energy; AMEn - apparent metabolizable energy corrected for nitrogen; NR - nitrogen retention; $\mathrm{CV}$ - coefficient of variation.

${ }^{1}$ Energy requirement according to Rostagno et al. (2005); Reduced in $100 \mathrm{kcal} / \mathrm{kg}$ in relation to the energy requirement. for metabolizability coefficient between the two levels of dietary energy.

The values of apparent metabolizable energy and apparent metabolizable energy corrected for nitrogen retention determined with 80 -week-old laying hens could enable formulations with inclusion of xylanase to provide superior performance compared with those birds fed diets nutritionally adequate without enzyme supplementation. However, information about the digestion and nutritional value of diets with the exogenous enzymes supplementation are important for nutritionists, once they probably enable low-cost formulations and may reduce the risk of having unbalanced nutrients (Cowieson et al., 2006).

\section{Conclusions}

The supplementation of xylanase increases the metabolizability coefficient of the dietary crude protein and improves the nitrogen retention of laying hens at 14 weeks of age. Xylanase, associated with adequate energy levels in the diet promotes higher values of apparent metabolizable energy and apparent metabolizable energy corrected for nitrogen determined with 80 -week-old laying hens.

\section{References}

BEDFORD, M.R. The effects of enzymes on digestion. Journal of Applied Poultry Research, v.5, p.370-378, 1996. 
CAMPBELL, G.L.; BEDFORD, M.R. Enzyme applications for monogastric feeds: A review. Canadian Journal of Animal Science, v.72, p.449-466, 1992.

CHOCT, M. Feed polysaccharides: nutritional roles and effect of enzymes. In: CONGRESSO LATINO AMERICANO DE NUTRIÇÃO ANIMAL, 4.; CLANA/CBNA/AMENA, 4., 2010. São Pedro. Anais... São Pedro: CBNA, 2010. p.65-78.

CHOCT, M.; HUGHES, R.J; WANG, J. et. al. Increased small intestinal fermentation is partly responsible for the antinutritive activity of nonstarch polysaccharides in chickens. British Poultry Science, v.37, p.609-621, 1996.

COLLINS, N.E.; MORAN, J.R.; STILBORN, HL. Influence of yellow dent maize hybrids having different kernel characteristics yet similar nutrient composition on broiler production. Journal of Applied Animal Research, v.10, p.228-235, 2001.

COSTA, F.G.P.; CLEMENTINO, R.H.; JACOME, I.M.T.D. et al. Utilizacao de um complexo multienzimatico em dietas de frangos de corte. Ciencia Animal Brasileira, v.5, n.2, p.63-71, 2004.

COWIESON, A.J. Factors that affect the nutritional value of maize for broilers. Animal Feed Science and Technology, n.119, p.293-305, 2005.

COWIESON, A.J.; SINGH, D.N.; ADEOLA, O. Prediction of ingredient quality and the effect of a combination of xylanase, amylase, protease and phytase in the diets of broiler chicks. 1. Growth performance and digestible nutrient intake. British Poultry Science, v.47, p.477-489, 2006.

JARONI, D.; SCHEIDELER, S.E; BECK, M. et. al. The effect of dietary wheat middlings and enzyme supplementation. II. Apparent nutrient digestibility, digestive tract size, gut viscosity, and gut morphology in two strains of leghorn hens. Poultry Science, v.78, p.1664-1674, 1999.

LEESON, S.; SUMMERS, J. D.; CASTON, L.J. Response of layers to low nutrient density diets. Journal of Applied Poultry Research, v.10, p.46-52, 2001.
LEESON, S.; SUMMERS, J.D. Commercial poultry nutrition. 2.ed. Ontário: University Book, 1997. 350p.

MATHLOUTHI, N.; MOHAMED, M.A.; LARBIER, M. Effect of enzyme preparation containing xylanase and $\beta$-glucanase on performance of laying hens fed wheat/barley- or maize/soybean meal-based diets. British Poultry Science, v.44, p.60-66, 2003.

MATTERSON, L.B.; POTTER, L.M.; STUTZ, M.W. et al. The metabolizable energy of feed ingredients for chickens. Research Report, v.7, p.3-11, 1965.

NOVAK, C.L.; YAKOUT, H.M.; REMUS, J. Response to varying dietary energy and protein with or without enzyme supplementation on growth and performance of leghorns: growing period. Journal of Applied Poultry Research, v.16, p.481-493, 2007.

NOVAK, C.L.; YAKOUT, H.M.; REMUS, J. Response to varying dietary energy and protein with or without enzyme supplementation on leghorn performance and economics. 2. laying period. Journal of Applied Poultry Research, v.17, p.17-33, 2008.

ROSTAGNO, H.S.; ALBINO, L.F.T.; DONZELE, J.L. et al. Tabelas brasileiras para suínos e aves: Composição de alimentos e exigências nutricionais. 2.ed. Viçosa, MG: UFV, 2005. 186p.

SAKOMURA, N.K.; ROSTAGNO, H.S. Métodos de pesquisa em nutrição de monogástricos. 1.ed. Jaboticabal: FUNEP, 2007. 283p.

SILVA, D.J.; QUEIROZ, A.C. Análises de alimentos (Métodos químicos e biológicos). 3.ed. Viçosa, MG: UFV, 2002. 235p.

SLOMINSKI, B.A. A new generation of enzymes for animal feeds. In: WESTERN NUTRITION CONFERENCE, 21., 2001, Winnipeg, Manitoba, Canada. Proceedings... Winnipeg, Manitoba, Canada, 2001. p.1-29.

VIANA, M.T.S. Suplementação de enzimas em dietas de poedeiras comerciais em postura. 2009. 119f. Tese (Doutorado em Zootecnia) - Universidade Federal de Viçosa, Viçosa, MG. 